\title{
Alternatives for Pragmatic Responses to Group Work Problems
}

\author{
Bill Davey \\ RMIT, Melbourne, Australia \\ bill.davey@rmit.edu.au
}

Karoly Bozan, Robert Houghton, and Kevin R. Parker Idaho State University, Pocatello, ID, USA

bozakaro@isu.edu; hougrobe@isu.edu; parkerkr@isu.edu

\begin{abstract}
Group work can provide a valuable learning experience, one that is especially relevant for those preparing to enter the information system workforce. While much has been discussed about effective means of delivering the benefits of collaborative learning in groups, there are some problems that arise due to pragmatic environmental factors such as the part time work commitments of students. This study has identified a range of problems and reports on a longitudinal Action Research study in two universities (in Australia and the USA). Over three semesters problems were identified and methods trialled using collaborative tools. Several promising solutions are presented to the identified problems, including the use of video tutorials and commentary using screen recordings as a means of providing feedback to students.
\end{abstract}

Keywords: action research, group work problems.

\section{Introduction}

Group work is required for those intending to enter the information systems profession and is necessary to derive maximum benefit from courses, particularly those involving systems analysis and design. While the benefits of collaborative learning and the very experience of working in groups have been well discussed (Barkley, Cross, \& Major, 2014; Kaye, 2012; O'Malley, 2012) there are everyday problems that must be taken into account (Boud, Cohen, \& Sampson, 2014). Gregory and Thorley (2013) contend "[i]f we are to exploit group-based learning fully we need to take into account its complexity, including issues such as structure; delivery; type of material; the basics of group dynamics; extent of preparation; and extent of social interaction" (p. 20).

In this study, academics from a University in the USA and another in Australia first identified

Material published as part of this publication, either on-line or in print, is copyrighted by the Informing Science Institute. Permission to make digital or paper copy of part or all of these works for personal or classroom use is granted without fee provided that the copies are not made or distributed for profit or commercial advantage AND that copies 1) bear this notice in full and 2) give the full citation on the first page. It is permissible to abstract these works so long as credit is given. To copy in all other cases or to republish or to post on a server or to redistribute to lists requires specific permission and payment of a fee. Contact Publisher@InformingScience.org to request redistribution permission. common problems of this pragmatic nature and then tried techniques to overcome those problems. Each was evaluated using Action Research principles and those that survived the analysis were reused and improved upon in following semesters. Reported here are methods of dealing with each problem that have shown promise in the light of student performance. 


\section{Method}

To examine group work challenges and to recommend improvements, we selected Action Research (AR) as our research method (Baskerville \& Wood-Harper, 1996; Checkland \& Holwell, 1996; Davison, Martinsons, \& Kock, 2004). This methodological approach was chosen because it "covers a broad array of research strategies that are dedicated to the integrated production of knowledge and the implementation of change" (O'Leary, 2004). AR is defined as a systematic review process initiated by practitioners to address identified challenges and ultimately enhance their own practice (Cochran-Smith \& Lytle, 1990; Ferrance, 2000; McCutcheon \& Jung, 1990; McNiff, 2002; Sagor, 1992; Shagoury \& Power, 2012). AR is a collaborative, repetitive situational methodology that is known for bridging theory and practice in different organizational environments (Susman \& Evered, 1978). AR is recognized as an effective tool to enhance teaching methods and student learning in educational settings (Cochran-Smith \& Lytle, 1993). The AR framework includes (1) the identification and investigation of problems or concerns recognized, (2) change designed and implanted in the practice with the goal of addressing the problem or concern identified, and (3) the effect of change is observed and analysed against pre-established measures to understand the impact of the change. AR is often approached as a multi-cycle process of the above sequential steps (Riel, 2007; Stringer, 2007), therefore, the observed outcome can guide the refinement of the design and implementation of change. The problem-solving cycle addressing work group challenges and the research cycle developing new knowledge have ongoing and systematic interaction (Chiasson, Germonprez, \& Mathiassen, 2008; Mckay \& Marshall, 2001). Relying on this interaction and its longitudinal outcomes, along with a variety of studies focusing on group work (Fearon, McLaughlin, \& Eng, 2012; Garbett, 2014; Hall \& Buzwell, 2013; Hansen, 2006; Pauli, Mohiyeddini, Bray, Michie, \& Street, 2008; Waite, Jackson, Diwan, \& Leonardi, 2004; Wolfe, 2008) we identified nine problems and developed solutioninterventions to improve the group work outcomes and make member contributions more even within and across groups. The study commenced in 2007 when an academic from the USA visited and taught in Australia. As a consequence of this visit, the process of jointly developing teaching materials commenced. In 2012 materials from Australia commenced being used in the USA and materials in the USA began being used in Australia. Observations were made informally during 2012 and 2013 and changes made to materials between the original two academics. The effect of these was discussed by email and Skype over this time. In 2015 the Australian visited the USA and the project was joined by two additional academics. A set of common problems was identified by discussion between the team and experiences around these common problems were collated.

This study describes the problems identified and the solutions proposed. We developed multiple techniques and implemented them in the classroom in a variety of classes. As the cross-national team of authors have experience in teaching in the "other" institution there were opportunities for the solutions proposed here to be monitored by an outside academic. This study includes only those techniques where we were certain of success or the students responded positively, or other evidence supported the use of the technique. Therefore, this report does not address every problem.

Across the five courses between Australia and the United States, we established the following measures:

- Number of non-contributing students

- Depth of analytics performed by students

- Breadth of analytical techniques students used during their projects

- Rate of on-time submission 
- Number of occasions when instructor is asked to mediate among team membersStudent feedback

- Peer review feedback

These outcomes are not intended to be rigorous to the extent that they are generalizable, but they constitute ideas tested in two real life situations over a significant number of iterations. All solutions were attempted over at least two semesters and some originated in 2007.

\section{Underlying Theories}

There are multiple streams of research into teaching under the circumstances described in these cases. Scott and Pollock (2006) have identified the need for group work, stating that the prevalence of teamwork in industry makes it incumbent upon universities to better prepare students for real life projects. However, the problems associated with group work must be anticipated and addressed. One study points out that team members commonly make unequal contributions in student groups (Staehr \& Byrne, 2011). Another study notes that group work can be afflicted by a lack of commitment and participation from some individuals (Whatley, 2012). This may be attributed to a variety of factors arising from students' contexts and environments, including human limitations in perception and processing, biases due to prior knowledge, skills, abilities, and information format preferences (Cohen, 2009).

The Informing Science Framework (Figure 1) captures the complexities involved in communication, as well as the potential sources of such complexity (Cohen, 2009). The enhanced model draws upon Shannon and Weaver's (1949) communication model and Wilson's (1981) model, and explains three components involved in communication: (1) the informer, (2) the medium, also referred to as the channel or communications pathway, and (3) the client or receiver of the communication (Reed \& Knight, 2013).

Viewed through an informing science lens, knowledge transfer is accomplished through the inter-

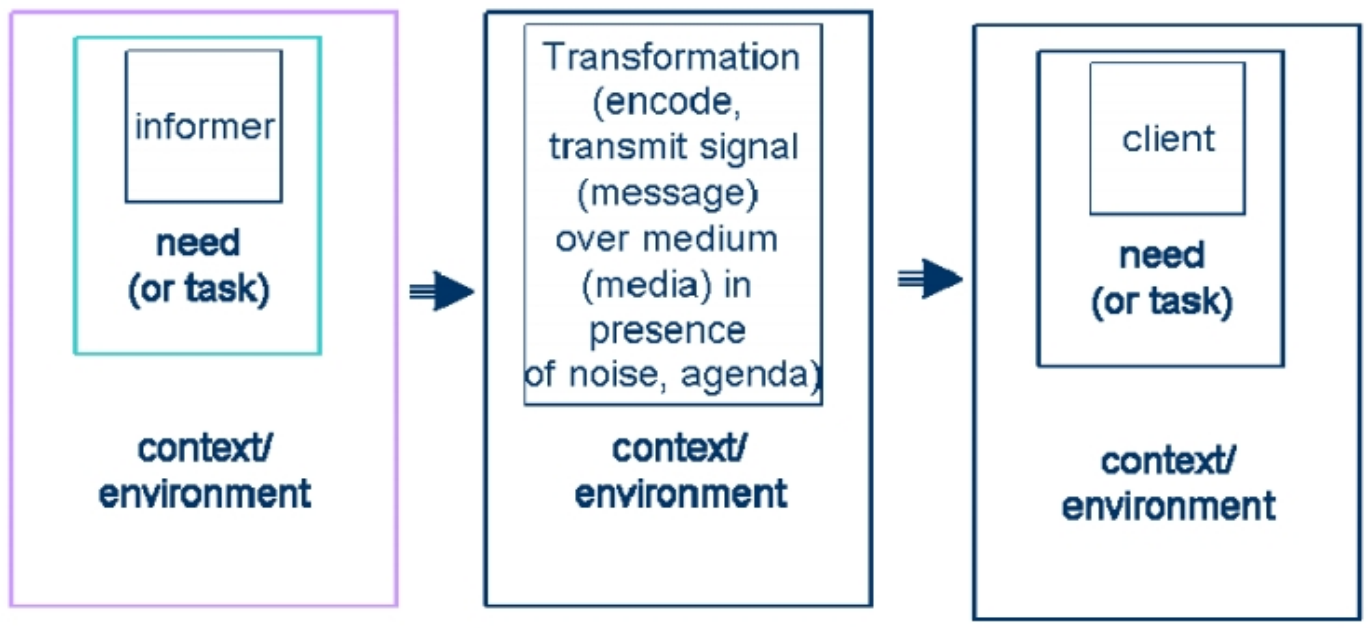

Figure 1. Cohen's (2009) Expanded Informing Science framework.

action of an informer, channel, and receiver within a complex environment (Murray \& Pérez, 2015). The framework depicts information transfer occurring between the sender of a message (informer) to a receiver of the message (client) via a delivery channel (transformation over medium) through which information is communicated (Sharp, Ryan, \& Prybutok, 2014). The framework also captures the need or task that drives the communication, as well as the contextual envi- 
ronment of the informer, information transmission and receiving media, and receiver of information that greatly impact them.

This transdiscipline initially focused on the direct information flow from an informer to a client. Within an educational context, the framework obviously relates to information flows between an instructor and a learner (Cheong, 2010). These dynamics mirror any learning situation wherein the informer is the educator, the client is the student, and the educational process both informs and is informed by interaction with the client (Murray \& Pérez, 2015).

However, the educational context includes a less obvious flow from student-to-student as it occurs in the context of group work (Cheong, 2010). Project-based group work is a complex informing situation in which student-to-student informing is critical since much of the work and learning occurs between students when not in the presence of the instructor. The transdiscipline has matured and broadened its focus to include these complex informing situations (Cheong, 2010). Project-based group work requires students to act alternately as "client-senders" or "clientrecipients" (Gill \& Cohen, 2008).

\section{The Cases}

There are shared characteristics of the two universities that need to be understood to put the results of the study in context. Firstly the academics are all involved in teaching information systems courses in colleges of business. Secondly the courses are taught in a mixture of face-to-face and online-only modes. Thirdly, the student populations are similar in the two cases: there are many students working part time and many students studying at a campus or venue that is geographically remote from the central campus of each university. These environmental factors mean that the online students must be supported by technology for ANY group work, and the face-toface students find it difficult to be in synchronous contact with their groups outside formal class times. The problems encountered may be due to the diverse nature of delivery that is common to the two institutions. Both universities have a Learning Management System: the Australians use Blackboard and the US site uses Moodle. Although these systems contain group interaction support, the systems were both found to be ineffective in handling the problems mentioned here due to the complexity of allowing students to control sharing of resources within their group.

\section{The Courses}

The Australian courses used for the study were:

- Digital Business Design and Innovation: A first year undergraduate course forming part of the information systems major and minor in a Bachelor of Business degree but also a popular elective for other degrees. This course is only offered face-to-face with a combination of interactive lectures and tutorials

- Internet for Business: an elective for most of the students undertaking the course, but also a course in a specialist minor in business analysis. This course is offered only online in Australia, but face-to-face in our campuses outside Australia.

The US courses used for the study were:

- Introduction to Informatics and Analytics: An upper division (third or fourth year) technology and application-based course to develop analytical and reasoning skills in the business domain. This is a required course for all students with a business major. This course is taught in multiple sections, with a section being one instance of a class. While most sections are face-to-face, one of the sections is an online only class, which is required to deliver the same topics as the other sections via an "online friendly" method. In- 
termediate to advanced skills are introduced and assessed through projects using business scenarios and real-life transactional data.

- Health Informatics: An upper division course, corresponding to a third or fourth year class, that introduces the technology and infrastructure that supports the clinical operations of a healthcare organization. Students from the College of Business majoring in health informatics and students from the School of Health Sciences take this class. This class was originally offered face-to-face, but in recent semesters an online-only sections has been offered.

- Systems Analysis and Design: An upper division course that provides a general understanding of the systems development life cycle, including both process-oriented and object-oriented approaches, as well as the development of web-based information systems. Students from business informatics, health informatics, and computer science are required to take this course to help them develop the analytical skills required to thoroughly understand a business's software needs and formulate the optimal solution. Both a faceto-face section and an online section are offered.

\section{Problems and Solutions}

The study found many practical problems in incorporating group work in the courses mentioned. Solutions were tried for many more problems than are mentioned here but the problems discussed here were experienced in all of the above courses.

\section{Problem 1}

In large lecture sections, groups are often formed for "in lecture exercises." Some students in these groups are under the impression that their contribution to these exercises will not be seen and therefore do not participate. They instead wait for "the answer", thus losing the power of the interactivity of the class.

\section{Proposed solution}

We have addressed this issue by using a form of Michaelsen's flipped classroom (Michaelsen, \& Sweet, 2011; Parmelee, Michaelsen, Cook, \& Hudes, 2012). Students are required to do preliminary work for each class, usually by visiting a business and making observations. Every student has a folder shared with their group and with the lecturer, and analysis tasks are then performed by each group using a shared document in their group folder. When each group has some meaningful response ALL group folders are potentially displayed on the large theatre screen and selected group work is shown to the whole class and used as the basis for discussion. This is done beginning with week one, so students are accustomed to using their computers in lectures and perform their work knowing their version may be displayed at any time. This has increased attendance in lectures every semester. It has also resulted in an increased number of student feedback on the value of lectures as opposed to tutorial-type work, although tutorials continue to be seen as more valuable.

\section{Problem 2}

Project-based online classes result in a great variation in the quality of group work submissions. A common issue is that students wait until the last minute and do not have enough time to submit a well-developed, quality project, which forms a large portion of their final grade. 


\section{Proposed solution}

It is common to assign a comprehensive project, which requires the use of skills learned in class to evaluate a real-life business problem (Kvale, 2006). The Health Informatics class requires students to develop questions in regards to user satisfaction of healthcare providers with their existing clinical information system. They are then required to identify system shortcomings based on the responses and develop a comprehensive solution or recommendation based on techniques and skills learned in class.

Breaking down the project and establishing interim graded milestones increased on-time submissions as well as the overall grades. Milestones make it possible for the instructor to determine the point at which students are experiencing difficulties and therefore provide more appropriate guidance. Student feedback indicated that the project provided an opportunity to see how all the "pieces fit together" that they learned throughout the semester.

Milestones are also used in the Systems Analysis and Design course. Students are responsible for turning in intermediate deliverables throughout the project. Dividing the large project into a series of milestones, or deliverables, is taught as a technique by which students can manage large projects (Parker, 2005). This approach forces the developer to meet deadlines or run the risk of falling farther and farther behind.

In the last session of the Health Informatics course, students were required to develop an eportfolio with the goal of showcasing the final project to current or future employees. In this way, students could demonstrate how skills learned in class were applied in real life situations.

The Australian contingent saw so much value in the USA trial of eportfolios that a reflective journal became part of their assessment regime.

\section{Problem 3}

Some students have time commitments that preclude full time study, forcing them to enrol in online courses (Boud et al., 2014). These students can become socially isolated, focussing only on completing assessment tasks. In such situations, the most common means of encouraging initial contact and interaction with a group is explicitly-assessed compulsory group interaction.

\section{Proposed solution}

The instructor may want to encourage the group to identify student strengths. Then student teams should divide the assessment exercise into sections and assign each team member an equal amount of deliverable. Each student is responsible for his or her own section and required to monitor others' contribution. The assigned sections are given to the tutor along with the final deliverable so that contributions can be individually assessed. In order to ensure that each student also understands other parts of the deliverable, their part needs to include how it fits in with the overall assignment.

This approach does not require any particular technology other than a platform that facilitates file sharing. Google Docs is ideal as it provides visibility to the others' work even in real time, so version control is not an issue. Email communication about task designation seems sufficient and real-time interaction is not required, which is a benefit for online students who have other commitments during the day.

We found that the clear expectations among team members prior to starting to work on an assignment increased the transparency and accountability of each student. The tutor may also monitor the sections assigned to a particular student through the course of the semester and identify that person's possible strengths and weaknesses. This can be beneficial for challenging students 
further in the area of their expertise and also help them to get familiar with subjects that they tend to disregard.

\section{Problem 4}

Online students require more frequent and more immediate feedback than face-to-face students. This can lead to inefficient teacher practises or the use of cheaper labour.

\section{Proposed solution}

It is imperative for online students to have some channel for asking questions. It is especially important in courses where technical skills are taught and hands-on assignments are given for students. We implemented numerous techniques, which were well received by students and increased the quality of deliverables.

First, a shared folder was established with the tutor, where students had to place all of their classrelated files. The tutor was able to monitor the progress and quality of the assignments for each student. It was no more time consuming than walking around in a lab session and assessing student work.

Second, screen recordings were provided to students to demonstrate each new concept and to explain each assignment. This allowed students to cover the new concept at their own pace and review sections multiple times as needed.

Third, responses to student questions were recorded using screen recording software. The instructor accessed the students' work from their shared folder and demonstrated how the students could resolve their issues. That guidance was recorded, and those screen recordings were made publicly available for the rest of the class so others could learn from them as well, just as in a face-to-face classroom. The videos were properly named and categorized, so students could find specific videos based on topics covered. This resulted in a knowledge repository that could be accessed by the class even after the semester was over.

These techniques were developed over multiple semesters based on student feedback. The videos were very well received and the shared folders and sharing tutorial videos were added in later and proved to be beneficial as well. The quality of assignments and student grades were significantly better as these techniques were established. Student enrolment increased in the online class as well, which may have been the result of positive student perception of the online class and word of mouth.

The class syllabus was also peer reviewed by instructors of other sections that were delivered face-to-face. It ensured that a similar topic list was covered in both face-to-face and online sections.

\section{Problem 5}

While the preceding two problems dealt with online courses, problems with group work are experienced in face-to-face courses as well. Face-to-face courses are not immune to feelings of isolation because many students in face-to face courses are still time poor, given that they work and are given time off to attend classes. However, they are still required to participate in group activities outside of class.

\section{Proposed solution}

This problem is most commonly addressed through the use of a collaborative tool, in particular the use of social media such as Facebook. However, some authors have reported that students are reluctant to use their Facebook accounts for school work as it infringes on their personal lives 
(Wang, Woo, Quek, Yang, \& Liu, 2012). A viable alternative is the use of Google Docs in a shared folder. The sharing of work with the group and with the tutor allows the tutor to give help asynchronously to the group, allows for students to work either synchronously or asynchronously, and allows for the work to be public to the group but private for all others. While our students used Facebook and Skype to aid communication, as noted above they were often reluctant to put their work on their personal Facebook accounts and valued having an option by which they could request feedback from the tutor prior to submission. Other solutions are integrated into the various learning management systems including, wikis, journals, and instance messaging systems.

\section{Problem 6}

Face-to-face groups and online groups often report the presence of a group member who does not put in much work. Groups are often wary of incorporating people they don't know and are suspicious that the assessment result will not reflect the work done by the individuals. Some students report that they have had an excessive burden due to the desire for a good group result and poor performance by group members.

\section{Proposed solution}

This solution is not novel but the means of implementing it may be (Kaufman, Felder, \& Fuller, 2000). A collaborative tool (Google Docs and a shared folder) are shared by group members and the tutor. All assessment tasks (and some preliminary tasks not assessed) are created by the group using colours. Each student chooses a colour and ANY contributions by them must be in that colour. Students are told at the start of the semester that each group member CAN be given an individual mark and that this will be decided on the basis of the quality of the work done in their colour. Student response to this rule is very positive at the start of the semester when announced. As the semester progresses the normal time constraints for some students (and the normal lack of motivation in some) becomes evident to the group. The tutor can also monitor this as the work is shared and a visual scan is sufficient to verify whether each colour is represented in the drafts as they grow. A typical response by the student group is a comment to be inserted in the work. Take a hypothetical student "Suzy" who is having relationship problems and has not started her contribution. The group will write, in Suzy's colour, "if Suzy wants to contribute she can write about the software architecture here." By the third semester of using this colour scheme the total number of non-contributing students in a population of 214 in the course was 2 . These included one who was hospitalized and one who had a family emergency in another country. The colour scheme also was reassuring to students doing the course late in their degree who had poor experiences in earlier courses involving group work - they were easily reassured that there was a mechanism in place to give them due credit without them doing "all the work for the group."

Peer evaluations or peer assessment can also be used to alleviate this concern, and those will be discussed in relation to the following, closely related problem.

\section{Problem 7}

Some students fail to engage in the course and with their groups. This is experienced in both online and face-to-face courses, but is especially common when students are located remotely and take an online course. If students are not able to meet with their groups there may be decreased accountability, because those students do not experience the negative peer pressure of personally admitting to their group members that they failed to contribute their fair share.

\section{Proposed solution}

Peer evaluations have long been an integral part of group based work (Boud, Cohen, \& Sampson, 1999; van den Berg, Admiraal, \& Pilot, 2006; van den Bogaard, \& Saunders-Smits, 2007). Each 
member of student teams can be required to submit a peer assessment form. For example, students taking Systems Analysis and Design must submit a Peer Evaluation Form. The syllabus states the following:

Since work is not done individually, peer evaluations will be used. The members of your project team may not all receive the same project grade. While grades are assigned to the overall project, each individual's grade will be determined by weighting that project grade by the results of a confidential peer evaluation. Each team member will be required to assess the contributions of all members of the team with regard to the percentage contributed by each member toward the successful completion of all phases of the project, and the cumulative scores for each team member will be averaged.

For example, if the project receives a score of 90, and team member \#1 is assessed an average contribution of $80 \%$ by all team members, then team member \#1 will receive a project score of 72 . On the other hand, if team member \#2 worked diligently and received an average contribution percentage of $100 \%$, then that team member will receive a score of 90.

Please note that if you fail to submit evaluations you will be assessed a penalty of one letter grade on your project score.

The categories on the peer evaluation form were developed by a group of students who did not think the original evaluation form was ideal. When they complained, they were challenged to come up with a better version. The opted to evaluate teammates in the following areas:

- Understanding of Class Material and Concepts Involved

- Leadership/Project Coordination

- Quality of Work (consider both the quality of ideas contributed as well as preparation of deliverables)

- Willingness to assist other team members

- Availability (consider accessibility via phone and e-mail as well as meeting attendance)

- Follow-through (did they do what they said)

- Amount of Input (their "fair share" or more should rate a 10)

- Research (consider both background material as well as tools used for presentation)

- Final Project Preparation

- Overall Contribution

\section{Problem 8}

Not all students have the same goals and motivation. Some students are high achievers and want to earn an A in the class, while others are satisficers who will do the bare minimum to pass the class. The dichotomy of expectations quickly leads to frustrations by both types.

\section{Proposed solution}

One approach that we have use in an attempt to avoid this is to require students to fill out a profile indicating their goal in the class, what grade they hope to attain, how hard they are willing to work, whether they have a full or part time job, if they live in the local community or commute, and times when they can meet. The instructors then attempt to match those with similar goals and characteristics, and students sign their profile as a "contract" committing them to behave as they indicated. 


\section{Problem 9}

Students get confused as to what parts of the group project have been accomplished and by whom, so they perform redundant work, wasting time and effort.

\section{Proposed solution}

Automatic versioning tools like Google Docs allow group members to review the precise revision history of the documents and data sets. Tools that allow student to keep their copies safe from error and disaster make it so they have fewer stresses about the project. Versioning tools give the students the knowledge that the document or data set they are working with is the latest version, and they can easily ascertain which portions need additional attention. Versioning reduces repetitive work. Students are taught how to set up a versioning system as part of saving a document.

\section{Discussion}

The experience of two teaching teams across two countries shows that there are difficulties in the delivery of degrees to the modern time-poor student. These may be peculiar to the pair of institutions in which the study was situated but may resonate with other teachers. The problems presented here are pragmatic and we expect them to be familiar to the experienced educator. For each solution trial the team used one of the following assessments anecdotally to ascertain that a proposed solution had a perceivable desired effect:

- Number of non-contributing students

- Depth of analytics performed by students

- Breadth of analytical techniques students used during their projects

- Rate of on-time submission

- Number of occasions when instructor is asked to mediate among team members

- Student feedback

- Peer review feedback

The instructor then reinforced the relevant aspects in the next semester. The solutions discussed above are those that showed the most positive results during the iterative trials. There is doubt that these techniques are ALL generalizable to any student population, but we are confident that they form a valuable set of considerations for the new academic looking to find ways around the problems posed.

\section{Conclusion}

Leading the Forbes list of ten skills employers most want in 2015 graduates is "Ability to work in a team structure" (Adams, 2014). Inside Higher Ed reports that the Association of American Colleges and Universities (AACU) surveyed employers and found they are more concerned about new graduates having a range of skills in areas like communication and team work than they are with a student's major (Jaschik, 2015). Clearly employers want new hires that have experienced working on teams, and it is essential that group work be incorporated into a variety of courses. However, although a literature search conducted by Laal and Ghodsi (2012) found many social benefits of collaborative learning, students may see those benefits negated when they encounter the problems addressed in this study. Instructors must work to address those problems while at the same time developing each student's sense of accountability and willingness to work cooperatively with others toward a common goal. By considering group work problems and viable solutions this study is a first step in realizing the full potential of group work. 


\section{References}

Adams, S. (2014). The 10 skills employers most want in 2015 graduates. Forbes. Retrieved December 13, 2015 from http://www.forbes.com/sites/susanadams/2014/11/12/the-10-skills-employers-most-wantin-2015-graduates/

Barkley, E. F., Cross, K. P., \& Major, C. H. (2014). Collaborative learning techniques: A handbook for college faculty. Hoboken, NJ: John Wiley \& Sons.

Baskerville, R. L., \& Wood-Harper, A. T. (1996). A critical perspective on action research as a method for information systems research. Journal of Information Technology, 11(3), 235-246.

Boud, D., Cohen, R., \& Sampson, J. (1999). Peer learning and assessment. Assessment and Evaluation in Higher Education, 2 (4), 413-426.

Boud, D., Cohen, R., \& Sampson, J. (Eds.). (2014). Peer learning in higher education: Learning from and with each other. New York: Routledge Publishing.

Checkland, P. B., \& Holwell, S. (1998). Action research: Its nature and validity. Systemic Practice and Action Research, 11(1), 9-21.

Cheong, C. (2010). From group-based learning to cooperative learning: A metacognitive approach to project-based group supervision. Informing Science: The International Journal of an Emerging Transdiscipline, 13, 73-86. Available from http://inform.nu/Articles/Vol13/ISJv13p073-086Cheong549.pdf

Chiasson, M. W., Germonprez, M., \& Mathiassen, L. (2008). Pluralist action research: A review of the information systems literature. Information Systems Journal, 19(1), 31-54.

Cochran-Smith, M., \& Lytle, S. (1990). Research on teaching and teacher research: The issues that divide. Educational Researcher, 19(2), 2-11.

Cochran-Smith, M., \& Lytle, S. (1993). Inside/outside: Teacher research and knowledge. New York: Teachers College Press.

Cohen, E. (2009). A philosophy of informing science. Informing Science: the International Journal of an Emerging Transdiscipline, 12, 1-15. Available from http://inform.nu/Articles/Vol12/ISJv12p001015Cohen399.pdf

Davison, R., Martinsons, M. G., \& Kock, N. (2004). Principles of canonical action research. Information Systems Journal, 14(1), 65-86.

Fearon, C., McLaughlin, H., \& Eng, T.Y. (2012). Using student group work in higher education to emulate professional communities of practice. Education + Training, 54(2/3), 114-125.

Ferrance, E. (2000). Action research. Northeast and Islands Regional Educational Laboratory at Brown University. Providence, RI. Retrieved March 12, 2016 from https://www.brown.edu/academics/education-alliance/sites/brown.edu.academics.educationalliance/files/publications/act_research.pdf

Garbett, C. (2014). Using collaborative social media for group work with distance learning students and with face to face students. ICERI2014 Proceedings, 4568-4575.

Gill, T., \& Cohen, E. (2008). Research themes in complex informing. Informing Science: the International Journal of an Emerging Transdiscipline, 11, 147-164. Retrieved from http://www.inform.nu/Articles/Vol11/ISJv11p147-164GillIntro.pdf

Gregory, R., \& Thorley, L. (2013). Introduction. In R. Gregory \& L. Thorley (Eds.), Using group-based learning in higher education (pp. 19-20). New York: Routledge Publishing.

Hall, D., \& Buzwell, S. (2013). The problem of free-riding in group projects: Looking beyond social loafing as reason for non-contribution. Active Learning in Higher Education, 14(1), 37-49.

Hansen, R. S. (2006). Benefits and problems with student teams: Suggestions for improving team projects. Journal of Education for Business, 82(1), 11-19. 
Jaschik, S. (2015). Well-prepared in their own eyes. Inside Higher Ed. Retrieved December 13, 2015 from https://www.insidehighered.com/news/2015/01/20/study-finds-big-gaps-between-student-andemployer-perceptions

Kaufman, D. B., Felder, R. M., \& Fuller, H. (2000). Accounting for individual effort in cooperative learning teams. Journal of Engineering Education, 89(2), 133-140.

Kaye, A. R. (2012). Computer supported collaborative learning. In C. O'Malley (Ed.), Computer supported collaborative learning (Vol. 128) (pp. 125-144). New York: Springer Science \& Business Media.

Kvale, S. (2006). A workplace perspective on school assessment. Workplace Learning SIG. Annual Conference of the American Educational Research Association. San Francisco, April.

Laal, M., \& Ghodsi, S. M. (2012). Benefits of collaborative learning. Procedia - Social and Behavioral Sciences, 31, 486-490. Retrieved December 13, 2015 from http://www.sciencedirect.com/science/article/pii/S1877042811030205

McCutcheon, G., \& Jung, B. (1990). Alternative perspectives on action research. Theory into Practice, 29, $144-151$.

Mckay, J., \& Marshall, P., (2001). The dual imperatives of action research. Information Technology and People, 14(1), 46-59.

McNiff, J. (2002). Action research for professional development: Concise advice for new action researchers (3rd ed.). Retrieved March 10, 2016 from http://jeanmcniff.com/ar-booklet.asp

Michaelsen, L. K., \& Sweet, M. (2011). Team-based learning. New Directions for Teaching and Learning, 128, 41-51.

Murray, M. C., \& Pérez, J. (2015). Informing and performing: A study comparing adaptive learning to traditional learning. Informing Science: the International Journal of an Emerging Transdiscipline, 18, 111-125. Available from http://www.inform.nu/Articles/Vol18/ISJv18p111-125Murray1572.pdf

O'Leary, Z. (2004). The essential guide to doing research. London: SAGE Publications.

O'Malley, C. [Ed.]. (2012). Computer supported collaborative learning (Vol. 128). New York: Springer Science \& Business Media.

Parmelee, D., Michaelsen, L. K., Cook, S., \& Hudes, P. D. (2012). Team-based learning: A practical guide: AMEE Guide No. 65. Medical Teacher, 34(5), e275-e287.

Parker, K. R. (2005). Lost river wind riders: A project for teaching database design. Communications of the Association for Information Systems, 16(24), 475-494.

Pauli, R., Mohiyeddini, C., Bray, D., Michie, D., \& Street, B. (2008). Individual differences in negative group work experiences in collaborative student learning. Educational Psychology, 28, 47-58.

Reed, A. H. \& Knight, L. V. (2013). Exploring the role of communication media in the informing science model: An information technology project management perspective. Informing Science: The International Journal of an Emerging Transdiscipline, 16, 131-145. Available from http://www.inform.nu/Articles/Vol16/ISJv16p131-145Reed0633.pdf

Riel, M. (2007). Understanding action research. Center for Collaborative Action Research. Retrieved March 10, 2016 from http://cadres.pepperdine.edu/ccar/define.html

Sagor, R. (1992). How to conduct collaborative action research. Alexandria, VA: Association for Supervision and Curriculum Development.

Scott, E., \& Pollock, M. (2006). Effectiveness of self-selected teams: A systems development project experience. Issues in Informing Science and Information Technology, 3, 601-617. Available from http://www.proceedings.informingscience.org/InSITE2006/IISITScot217.pdf

Shagoury, R., \& Power, B. (2012). Living the questions: A guide for teacher-researchers. Portland, ME: Stenhouse. 
Shannon, C. E., \& Weaver, W. (1949). The mathematical theory of communication. Urbana, Illinois: The University of Illinois Press.

Sharp, J. H., Ryan, S. D., \& Prybutok, V. R. (2014). Global agile team design: An informing science perspective. Informing Science: the International Journal of an Emerging Transdiscipline, 17, 175-187. Retrieved from http://www.inform.nu/Articles/Vol17/ISJv17p175-187Sharp0653.pdf

Staehr, J., \& Byrne, J.G. (2011). Improving teaching and learning in an information systems subject: A work in progress. Issues in Informing Science and Information Technology, 8, 13-23. Available from http://iisit.org/Vol8/IISITv8p013-023Staehr222.pdf

Stringer, E. T. (2007). Action research. Los Angeles: Sage.

Susman, G. I., \& Evered, R. D. (1978). An assessment of the scientific merits of action research. Administrative Science Quarterly, 23(4), 582-603.

van den Berg, I, Admiraal, W., \& Pilot, A (2006) Peer assessment in university teaching: Evaluating seven course designs. Assessment and Evaluation in Higher Education, 31(1), 19-36.

van den Bogaard, M. E. D., \& Saunders-Smits, G. N. (2007). Peer \& self evaluations as means to improve the assessment of project based learning. $37^{\text {th }}$ ASEE/IEEE Frontiers in Education Conference - Global Engineering: Knowledge Without Borders, Opportunities Without Passports. pp.S1G-12-S1G-18.

Waite, W. M., Jackson, M. H., Diwan, A., \& Leonardi, P. M. (2004). Student culture vs group work in computer science. ACM SIGCSE Bulletin, 36(1), 12-16.

Wang, Q., Woo, H. L., Quek, C. L., Yang, Y., \& Liu, M. (2012). Using the Facebook group as a learning management system: An exploratory study. British Journal of Educational Technology, 43(3), 428438.

Whatley, J. (2012). Evaluation of a team project based learning module for developing employability skills. Issues in Informing Science and Information Technology, 9, 75-92. Available from http://iisit.org/Vol9/IISITv9p075-092Whatley096.pdf

Wilson, T. D. (1981). On user studies and information needs. Journal of Documentation, 37(1), 3-15. Available from http://www.asiaa.sinica.edu.tw/ ccchiang/GILIS/LIS/p658-Wilson.pdf

Wolfe, A. (2008). Student attitudes toward team projects. Proceedings of the Marketing Management Association (MMA) 2008 Spring Conference, Chicago, Illinois. Available from http://alisonwolfe.com/wordpress/wp-content/uploads/Student_Attitudes_Team_Projects1.pdf

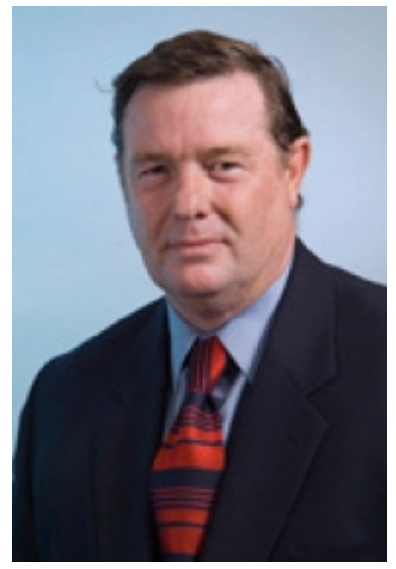

\section{Biographies}

Dr. Bill Davey is a Senior Lecturer in the School of Business Information Technology at RMIT University, Melbourne, Australia. His research interests include methodologies for systems analysis and systems development, information systems curriculum, eGovernment and the elderly, and information technology in educational management. Bill and Kevin have worked together co-operatively on many occasions. They have co-operated on several joint research projects and coauthored several papers relating to management information systems, programming, computers in management, eGovernment and the elderly, and IS curriculum. 


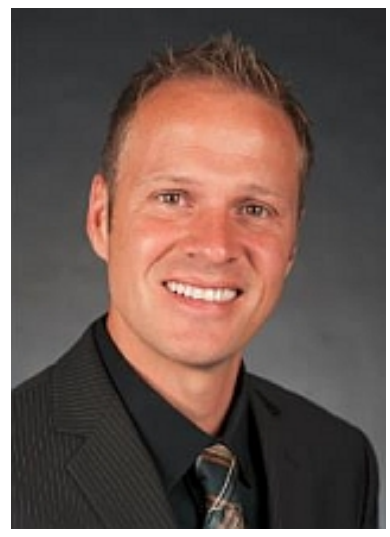

Dr. Karoly Bozan is an Assistant Professor of Informatics and Computer Science at Idaho State University. Dr. Bozan's research interests encompass system design in the health domain in the multi-stakeholder context. Dr. Bozan holds a B.B.A. in Finance (2000), an M.B.A. (2009), and a Ph.D. in Information Systems (2014) from Kent State University.

Prior to joining academia, Dr. Bozan held numerous technical and management consulting positions in a variety of industries.

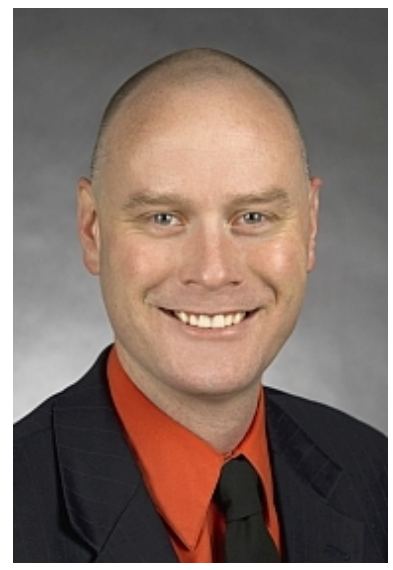

Robert F. Houghton is an Associate Professor of Informatics and Computer Science at Idaho State University. He has specialized in the hardware aspect of Informatics. His research focuses upon informatics security with human-computer integration. His background in informatics security provides a large knowledge base for sharing experiences with HIPAA, FERPA, and PCI data security standards. Dr. Houghton holds an M.S. in Management Information Systems from Utah State University (2008) and a Ph.D. in Management Information Systems from Utah State University (2013). Prior to joining academia, Dr. Houghton served as a Systems Administrator and a Network Security Specialist at Utah State University. Dr. Houghton joined Idaho State University in 2014.

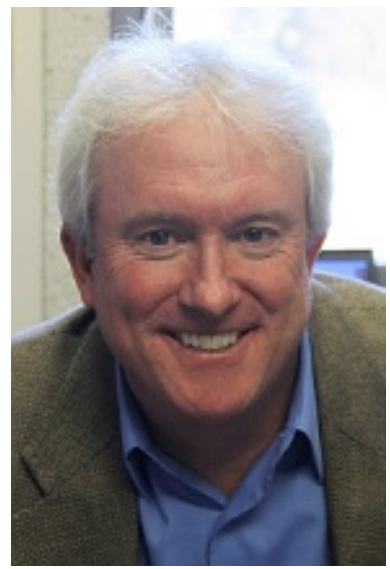

Dr. Kevin R. Parker is Chair and Professor of the Department of Informatics and Computer Science at Idaho State University. Parker's research interests include eGovernment and the elderly, business intelligence, and the impact of developments in informatics on curriculum. Dr. Parker holds a B.A. in Computer Science from the University of Texas at Austin (1982), an M.S. in Computer Science from Texas Tech University (1991), and a Ph.D. in Management Information Systems from Texas Tech University (1995). He chairs an interdisciplinary academic department that spans the College of Business and the College of Science and Engineering, and offers degrees in business informatics, health informatics, and computer science. 